\title{
The mobile-phone-based iCO ${ }^{\mathrm{TM}}$ Smokerlyzer ${ }^{\mathrm{R}}$ : Comparison with the piCO ${ }^{+}$Smokerlyzer ${ }^{\mathrm{B}}$ among smokers undergoing methadone-maintained therapy
}

\author{
Hsui Yang Wong', Muniswary Subramaniyan' ${ }^{1}$, Chris Bullen' ${ }^{2}$, Amer Siddiq A. N. ${ }^{1}$, Mahmoud Danaee $^{3}$, Anne Yee
}

\begin{abstract}
INTRODUCTION The mobile-phone-based Bedfont iCO $^{\text {TM }}$ Smokerlyzer ${ }^{\circledR}$ is of unknown validity and reproducibility compared to the widely-used $\mathrm{piCO}^{+} \mathrm{Smokerlyzer}^{\circledR}$. We aimed to compare the validity and reproducibility of the $\mathrm{iCO}^{\mathrm{TM}}$ Smokerlyzer $^{\circledR}$ with the piCO ${ }^{+}$Smokerlyzer ${ }^{\circledR}$ among patients reducing or quitting tobacco smoking.

METHODS Methadone-maintained therapy (MMT) users from three centers in Malaysia had their exhaled carbon monoxide (eCO) levels recorded via the $\mathrm{piCO}^{+}$ and $\mathrm{iCO}^{\mathrm{TM}}$ Smokerlyzers ${ }^{\circledR}$, their nicotine dependence assessed with the Malay version of the Fagerström Test for Nicotine Dependence (FTND-M), and daily tobacco intake measured via the Opiate Treatment Index (OTI) Tobacco Q-score. Pearson partial correlations were used to compare the eCO results of both devices, as well as the corresponding FTND-M scores.

RESULTS Among the 146 participants (mean age 47.9 years, $92.5 \%$ male, and $73.3 \%$ Malay ethnic group) most (55.5\%) were moderate smokers (6-19 cigarettes/day). Mean eCO categories were significantly correlated between both devices $(\mathrm{r}=0.861$, $\mathrm{p}<0.001)$, and the first and second readings were significantly correlated for each device $\left(\mathrm{r}=0.94\right.$ for the $\mathrm{piCO}^{+}$Smokerlyzer $^{\circledR}, \mathrm{p}<0.001 ; \mathrm{r}=0.91$ for the $\mathrm{iCO}^{\mathrm{TM}}$ Smokerlyzer $\left.{ }^{\circledR}, \mathrm{p}<0.001\right)$. Exhaled CO correlated positively with FTND-M scores for both devices. The post hoc analysis revealed a significantly lower $\mathrm{iCO}^{\mathrm{TM}}$ Smokerlyzer ${ }^{\circledR}$ reading of $0.82(95 \%$ CI: $0.69-0.94, p<0.001)$ compared to that of the piCO $^{+}$Smokerlyzer $^{\circledR}$, and a significant intercept of -0.34 (95\% CI: -0.61 $--0.07, p=0.016$ ) on linear regression analysis, suggesting that there may be a calibration error in one or more of the $\mathrm{iCO}^{\mathrm{TM}}$ Smokerlyzer ${ }^{\circledR}$ devices.

CONCLUSIONS The iCO ${ }^{\mathrm{TM}}$ Smokerlyzer ${ }^{\circledR}$ readings are highly reproducible compared to those of the $\mathrm{piCO}^{+}$Smokerlyzer $^{\circledR}$, but calibration guidelines are required for the mobile-phone-based device. Further research is required to assess interchangeability.
\end{abstract}

\section{AFFILIATION \\ 1 Department of Psychological Medicine, University of Malaya Center of Addiction Sciences (UMCAS), Kuala Lumpur, Malaysia \\ 2 National Institute for Health Innovation, The University of Auckland, Auckland, New Zealand 3 Department of Social and Preventive Medicine, University of Malaya, Kuala Lumpur, Malaysia}

CORRESPONDENCE TO Anne Yee. Department of Psychological Medicine, University of Malaya Center of Addiction Sciences (UMCAS), University of Malaya, 50603 Kuala Lumpur, Malaysia.

E-mail: annyee17@um.edu.my.

KEYWORDS

nicotine, cessation, nicotine dependence, smoking/harm reduction

Received: 8 July 2019 Revised: 26 July 2019

Accepted: 26 July 2019

\section{INTRODUCTION}

Objective smoking measures are useful to verify selfreported smoking status by individuals participating in harm reduction or smoking cessation interventions and studies ${ }^{1}$. Exhaled carbon monoxide (eCO) is widely used for these purposes because it is less expensive and less invasive than other measures, such as serum or urinary cotinine, and provides immediate results that assist in motivating patients to quit ${ }^{1,2}$. The $\mathrm{piCO}^{+}$Smokerlyzer $^{\circledR}$ is commonly used to measure $\mathrm{eCO}$ levels in clinical and research settings ${ }^{3}$ because of its high validity and reproducibility in discriminating smokers from non-smokers ${ }^{4-6}$.

To date, the validity and reproducibility of the 
$\mathrm{iCO}^{\mathrm{TM}}$ Smokerlyzer ${ }^{\circledR 7}$, an eCO measuring device designed for use with a smartphone and marketed primarily as a self-monitoring tool, is unknown. If found to perform as well as the piCO+ $\mathrm{Smokerlyzer}^{\circledR}$, despite being intended for single-patient use, the iCO $^{\text {TM }}$ Smokerlyzer $^{\circledR}$ could potentially be a research tool in smoking intervention studies, and at a lower cost. In clinical settings, the $\mathrm{iCO}^{\mathrm{TM}}$ Smokerlyzer ${ }^{\circledR}$ may also be useful where limited devices are available and where frequent monitoring may support therapeutic goals such as harm reduction for individuals on methadone-maintenance therapy (MMT) $)^{8,9}$.

This exploratory study aimed to compare the validity and reproducibility of the $\mathrm{iCO}^{\mathrm{TM}}$ Smokerlyzer $^{\circledR}$ with those of the $\mathrm{piCO}^{+} \mathrm{Smokerlyzer}^{\circledR}$, and correlate eCO levels with an established measure of nicotine dependence.

\section{METHODS}

\section{Study design}

Participants from three methadone clinics (University Malaya Medical Center, San Peng, and Chow Kit) in Kuala Lumpur, Malaysia were recruited from December 2017 to January 2018. Participants who were aged $\geq 18$ years, on MMT for two months or more, who had an established therapeutic compliance and were not on marijuana or any other recreational drugs (as determined by routine urinary drug tests), and smoked at least one cigarette daily for the past one month, were approached for consent to take part in the study. Participants who could not understand the device instructions or who were medically unstable were excluded. The Medical Ethical Committee of University Malaya Medical Center approved the study protocol (MECID: 20146-331).

\section{Procedure}

Sociodemographic data were obtained and the Malay version of the Fagerström Test for Nicotine Dependence (FTND-M) was administered ${ }^{10}$. This instrument has moderate validity in distinguishing smokers with nicotine dependence from their nonnicotine-dependent counterparts with a cut-off of 2 , and positively correlates with piCO $^{+}$Smokerlyzer $^{\circledR}-$ measured eCO levels ${ }^{10,11}$.

The tobacco Q-score ${ }^{12}$ was calculated by dividing by two the total number of cigarettes consumed on the two days before the day of the study, enabling each participant to be categorized as light ( $\leq 5$ cigarettes) day), moderate (6-19 cigarettes/day) or heavy smoker $(\geq 20 \text { cigarettes/day })^{13,14}$.

Both devices were sanitized with anti-bacterial cleaning wipes between participants as per manufacturer recommendations ${ }^{3,7}$, using makeshift single-use mouthpieces for both devices to reduce transmission of fluids between participants; the smartphone Smokerlyzer application was used with the $\mathrm{iCO}^{\mathrm{TM}}$ Smokerlyzer $^{\circledR}$. The instructions for both devices were: to completely exhale, take a deep breath, hold the breath for $15 \mathrm{~s}$, and exhale completely and slowly into each device, which yielded values in parts per million ( $\mathrm{ppm}$ ). Each participant provided four samples with 5-minute intervals between samples, beginning with the piCO $^{+} \mathrm{Smokerlyzer}^{\circledR}$, and alternating with the $\mathrm{iCO}^{\mathrm{TM}}$ Smokerlyzer ${ }^{\circledR}$.

\section{Data analysis}

Descriptive statistics were used to examine characteristics data. The $\mathrm{piCO}^{+}$Smokerlyzer $^{\circledR}$ readings were converted into ordinal categories $(0-6 ; 7-10$; $11-15 ; 16-20 ; 21-25 ; 26-30$; and $\geq 31 \mathrm{ppm})$ to be compared with the ordinal categories in the initial results interface obtained from the $\mathrm{iCO}^{\mathrm{TM}}$ Smokerlyzer ${ }^{\circledR}$; category readings from both devices were averaged for further analyses.

Partial correlations adjusting for covariates of age, tobacco Q-score and FTND-M scores, which were found to significantly influence the correlation between piCO $^{+}$and $\mathrm{iCO}^{\mathrm{TM}}$ Smokerlyzer ${ }^{\circledR}$ readings, were performed using SPSS v25. Additionally, correlations between first and second $\mathrm{piCO}^{+}$and $\mathrm{iCO}^{\mathrm{TM}}$ Smokerlyzer ${ }^{\circledR}$ readings and between the $\mathrm{iCO}^{\mathrm{TM}}$ Smokerlyzer $^{\circledR}$ readings and FTND-M scores were also performed.

\section{RESULTS}

The participants' mean age was 47.9 years (Table 1 ). The average daily methadone dose was $69.7 \mathrm{mg}$, the mean tobacco Q-score was 12.3 cigarettes/day and the mean FTND-M score was 3.9. Most participants were male (92.5\%), Malay (73.3\%) and moderate smokers (55.5\%).

Mean eCO levels were significantly correlated between both devices $(r=0.86, p<0.001$; Figure 1$)$, after adjusting for covariates of age, tobacco Q-score and FTND-M score. First and second device readings 
Table 1. Baseline sociodemographic characteristics of study subjects $(\mathrm{N}=146)$

\begin{tabular}{|c|c|c|}
\hline Variable & Vean & SE \\
\hline Age (years) & 47.89 & 0.85 \\
\hline Daily methadone dose (mg) & 69.69 & 2.79 \\
\hline Tobacco 0-score (cigarettes/day) & 12.25 & 0.67 \\
\hline \multirow{2}{*}{$\begin{array}{l}\text { Malay version of the Fagerström Test for } \\
\text { Nicotine Dependence (FTND-M) score }\end{array}$} & 3.94 & 0.17 \\
\hline & n & $\%$ \\
\hline \multicolumn{3}{|l|}{ Gender } \\
\hline Male & 137 & 93.8 \\
\hline Female & 9 & 6.2 \\
\hline \multicolumn{3}{|l|}{ Race } \\
\hline Malay & 107 & 73.3 \\
\hline Chinese & 26 & 17.8 \\
\hline Indian & 12 & 8.2 \\
\hline Other & 1 & 0.7 \\
\hline \multicolumn{3}{|l|}{ Tobacco 0-score category (cigarettes/day) } \\
\hline Light smoker $(\leq 5)$ & 28 & 19.2 \\
\hline Moderate smoker (6-19) & 81 & 55.5 \\
\hline Heavy smoker $(\geq 20)$ & 37 & 25.3 \\
\hline
\end{tabular}

were significantly correlated with each other, after controlling for the same covariates $(r=0.94$ for categorical values of the $\mathrm{iCO}^{\mathrm{TM}}$ Smokerlyzer ${ }^{\circledR}, \mathrm{p}<0.001$; $\mathrm{r}=0.91$ for integer values of the $\mathrm{piCO}^{+}$Smokerlyzer $^{\circledR}$, $\mathrm{p}<0.001 ; \mathrm{r}=0.86$ for categorical values of the $\mathrm{piCO}^{+}$ Smokerlyzer $\left.{ }^{\circledR}, \mathrm{p}<0.001\right)$. Post hoc analyses using the Bonferroni procedure revealed that $\mathrm{iCO}^{\mathrm{TM}}$ Smokerlyzer ${ }^{\circledR}$ readings were significantly lower than the corresponding piCO $^{+}$Smokerlyzer $^{\circledR}$ readings by 0.82 (95\% CI: 0.69-0.94, p<0.001), and subsequent linear regression analyses confirmed a significant intercept of -0.34 (95\% CI: $-0.61--0.07, \mathrm{p}=0.016)$. Mean eCO levels of the $\mathrm{iCO}^{\mathrm{TM}}$ Smokerlyzer ${ }^{\circledR}$ positively correlated with FTND-M scores $(\mathrm{r}=0.22, \mathrm{p}<0.01)$.

\section{DISCUSSION}

In this exploratory study, the significant correlation found between the readings of the $\mathrm{iCO}^{\mathrm{TM}}$ Smokerlyzer ${ }^{\circledR}$ and the $\mathrm{piCO}^{+}$Smokerlyzer $^{\circledR}$, indicates that the $\mathrm{iCO}^{\mathrm{TM}}$ Smokerlyzer ${ }^{\circledR}$ may have validity equivalent to the piCO $^{+}$Smokerlyzer $^{\circledR}$ device that has been shown to

Figure 1. Weighted correlation (larger circles imply higher frequencies of individuals, and smaller circles imply lower frequencies of individuals) between exhaled carbon monoxide (eCO) level categories taken with the iCO $^{T M}$ Smokerlyzer ${ }^{R}$ and the piCO Smokerlyzer ${ }^{R}$.

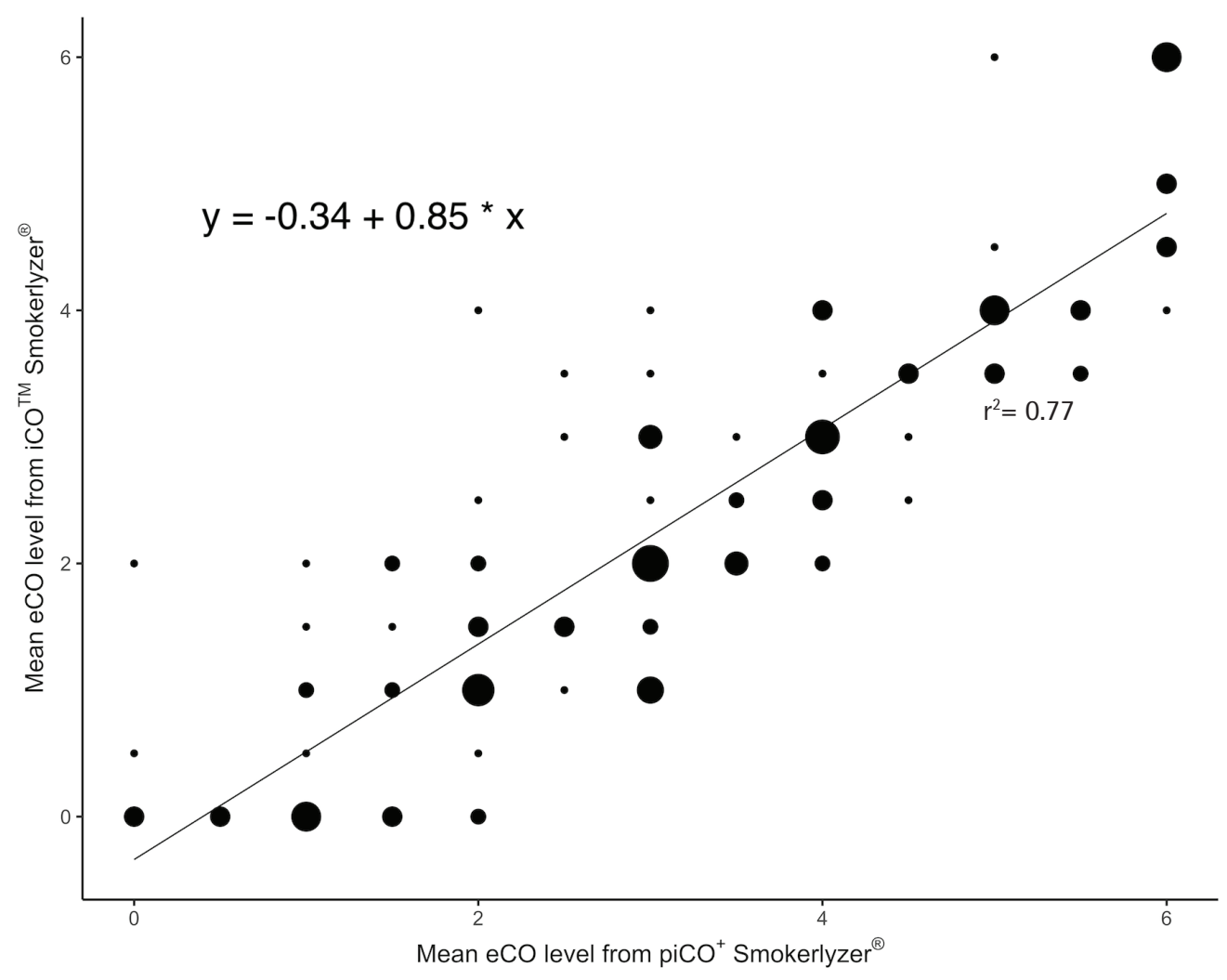


be highly valid in discriminating between smokers and non-smokers ${ }^{4-6}$. With regard to reproducibility of the $\mathrm{iCO}^{\mathrm{TM}}$ Smokerlyzer ${ }^{\circledR}$, both readings were significantly correlated $(\mathrm{r}=0.94)$. Interestingly, the corresponding piCO $^{+}$Smokerlyzer $^{\circledR}$ value was lower $(r=0.91$ for raw values, $r=0.86$ when in grouped categories, $p<0.001$ for all three correlations), suggesting that the $\mathrm{iCO}^{\mathrm{TM}}$ Smokerlyzer ${ }^{\circledR}$ performed very well in terms of reproducibility when grouped into categories.

Additionally, the post hoc analysis finding and subsequent regression analyses with a significant intercept (Figure 1) suggest that one or more of the iCO $^{\text {TM }}$ Smokerlyzer ${ }^{\circledR}$ devices may be consistently yielding underestimates of eCO levels. Therefore, further guidelines are needed to recognize and rectify this calibration error, indicating that routine checks are needed against another calibrated device such as the piCO $^{+}$Smokerlyzer $^{\circledR}$. Finally, the finding that eCO levels of the $\mathrm{iCO}^{\mathrm{TM}}$ Smokerlyzer ${ }^{\circledR}$ correlated $^{-}$ positively with the FTND-M scores warrants further research on whether reducing smoking in people with high nicotine dependence is a step towards smoking cessation.

This study did not assess raw values of the $\mathrm{iCO}^{\mathrm{TM}}$ Smokerlyzer ${ }^{\circledR}$ or abstinence cut-off points, thus restricting further analyses, such as BlandAltman analysis, and the potential as a clinical utility. A study by Karelitz et al. ${ }^{15}$ had demonstrated lack of agreement and differences of 1.5-6.0 ppm between both monitors, thereby suggesting a lack of interchangeability between readings of both monitors. Additionally, the iCO ${ }^{\mathrm{TM}}$ Smokerlyzer ${ }^{\circledR}$ has a cited accuracy of $15 \%$ for each $1 \mathrm{ppm}^{7}$, compared to $<3 \%$ for the $\mathrm{piCO}^{+} \mathrm{Smokerlyzer}^{\circledR 3}$. Consequently, the use of broad categories may indeed be supported, aiming to reduce the differences between devices, and in the process potentially increase interchangeability between readings of both monitors, which would need to be confirmed through further research.

Nevertheless, assessing the $\mathrm{iCO}^{\mathrm{TM}}$ Smokerlyzer ${ }^{\circledR}$ against the piCO+ Smokerlyzer $^{\circledR}$ has yielded some results of clinical significance. The piCO ${ }^{+}$Smokerlyzer $^{\circledR}$ has been extensively studied and shown to be reproducible and reasonably accurate in determining patients who are abstinent, based on objective scores ${ }^{4-6}$. This study demonstrates that the categories obtained from the

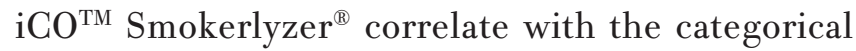
grouped integers shown on the piCO+ $\mathrm{Smokerlyzer}^{\circledR}$.
As such, there is a possibility for the more economical and user-friendly iCO ${ }^{\mathrm{TM}}$ Smokerlyzer ${ }^{\circledR}$ to be researched in greater detail in order to assess its suitability for use in research and clinical environments.

\section{CONCLUSIONS}

The $\mathrm{iCO}^{\mathrm{TM}}$ Smokerlyzer ${ }^{\circledR}$ yielded highly reproducible results that are potentially comparable to the $\mathrm{piCO}^{+}$ Smokerlyzer ${ }^{\circledR}$, pending further calibration guidelines. As a more economical and user-friendly device than the piCO $^{+}$Smokerlyzer $^{\circledR}$, the iCO $^{\text {TM }}$ Smokerlyzer ${ }^{\circledR}$ therefore has potential use in smoking cessation studies. Additionally, many individuals could benefit from using the $\mathrm{iCO}^{\mathrm{TM}}$ Smokerlyzer ${ }^{\circledR}$, to assess the true extent of their cigarette consumption, such that behavioral and pharmacological smoking interventions may be studied and implemented in a timely manner.

\section{REFERENCES}

1. Bittoun R. Carbon Monoxide Meter: The Essential Clinical Tool — the 'Stethoscope' — of Smoking Cessation. J Smok Cessat. 2008;3(2):69-70. doi:10.1375/jsc.3.2.69

2. Krishnan N, Elf JL, Chon S, Golub JE. COach2Quit: A pilot randomized controlled trial of a personal carbon monoxide monitor for smoking cessation. Nicotine Tob Res. 2018; doi:10.1093/ntr/nty182

3. Bedfont Scientific Ltd. piCO ${ }^{+\mathrm{TM}}$ Smokerlyzer ${ }^{\oplus}$ : Operating manual. https://www.bedfont.com/file. php?f=ZmlsZSMjNzE0. Published June, 2014. Accessed May 7, 2019.

4. Raiff BR, Faix C, Turturici M, Dallery J. Breath carbon monoxide output is affected by speed of emptying the lungs: Implications for laboratory and smoking cessation research. Nicotine Tob Res. 2010;12(8):834-838. doi:10.1093/ntr/ntq090

5. Meredith SE, Robinson A, Erb P, et al. A mobile-phonebased breath carbon monoxide meter to detect cigarette smoking. Nicotine Tob Res. 2014;16(6):766-773. doi:10.1093/ntr/ntt275

6. Erb P, Raiff BR, Meredith SE, Dallery J. The accuracy of a lower-cost breath carbon monoxide meter in distinguishing smokers from non-smokers. J Smok Cessat. 2015;10(1):59-64. doi:10.1017/jsc.2013.37

7. Bedfont Scientific Limited Ltd. iCO ${ }^{\mathrm{TM}}$ Smokerlyzer ${ }^{\circledR}$ : User Manual. https://www.bedfont.com/file. php?f=ZmlsZSMjMTczMw==. Published November, 2015. Accessed May 7, 2019.

8. Guydish J, Passalacqua E, Tajima B, Chan M, Chun J, Bostrom A. Smoking prevalence in addiction treatment: A review. Nicotine Tob Res. 2011;13(6):401-411. doi:10.1093/ntr/ntr048

9. Zirakzadeh A, Shuman C, Stauter E, Hays JT, Ebbert JO. 
Cigarette smoking in methadone-maintained patients: an up-to-date review. Curr Drug Abuse Rev. 2013;6(1):7784. doi:10.2174/1874473711306010009

10. Yee AHA, Ng CG, Rusdi AR. Validation of the Malay version of Fagerstrom test for nicotine dependence (FTND-M) among a group of male staffs in a University Hospital. MJP. 2011;20(1). https://www.mjpsychiatry. org/index.php/mjp/article/view/136/114. Accessed December 8, 2017.

11. Ng CG, Yee AHA. Exhaled carbon monoxide levels among Malaysian male smokers with nicotine dependence. Southeast Asian J Trop Med Public Health. 2012;43(1):212-218.

12. Darke S, Ward J, Hall W, Heather N, Wodak A. Opiate Treatment Index (OTI) Manual. Technical Report 11. Sydney: National Drug and Alcohol Research Centre; 1991. https://ndarc.med.unsw.edu.au/sites/default/files/ ndarc/resources/TR.011.pdf. Accessed July 8, 2019.

13. Frosch DL, Shoptaw S, Nahom D, Jarvik ME. Associations between tobacco smoking and illicit drug use among methadone-maintained opiate-dependent individuals. Exp Clin Psychopharmacol. 2000;8(1):97-103.

14. Neumann T, Rasmussen M, Heitmann BL, Tønnesen H. Gold standard program for heavy smokers in a real-life setting. Int J Environ Res Public Health. 2013;10(9):4186-4199. doi:10.3390/ijerph10094186

15. Karelitz JL, Michael VC, Perkins KA. Analysis of agreement between expired-air carbon monoxide monitors. J Smok Cessat. 2017;12(2);105-112. doi:10.1017/jsc.2015.18
ACKNOWLEDGEMENTS

The authors thank the Malaysian National Anti-Drug Agency (Agensi Anti-Dadah Kebangsaan, AADK) for its participation, support and cooperation. The findings and conclusions in this report are those of the authors and do not necessarily represent the official position of AADK.

\section{CONFLICTS OF INTEREST}

The authors declare that they have no competing interests, financial or otherwise, related to the current work. C. Bullen reports personal fees from Johnson \& Johnson KK Consumer Company Japan, outside the submitted work. A. Nordin reports grants from Johnson \& Johnson Malaysia and personal fees from Lundbeck Malaysia, outside the submitted work. The rest of the authors have also completed and submitted an ICMJE form for disclosure of potential conflicts of interest.

\section{FUNDING}

This work was supported by a University of Malaya grant GC004B-HTM. The funders had no role in the analysis or interpretation of the study or its results.

\section{AUTHORS' CONTRIBUTIONS}

C.B. conceived the idea for this study. A.Y., H.Y.W., M.D. and M.S. conceptualized the research aims and analytic plan, and, together with A.S.A.N, interpreted the results. All authors contributed to the writing of the manuscript and approved its final version.

PROVENANCE AND PEER REVIEW

Not commissioned; externally peer reviewed. 